ECREG STUDIES

Vol. 14, No. 1, 2021 www.ers.edu.pl PDF OPEN ACCESS eISSN 2451-182X

Authors' contribution/

Wkład autorów:

A. Study design/ Zaplanowanie badań

B. Data collection/ Zebranie danych

C. Statistical analysis/ Analiza statystyczna

D. Data interpretation/ Interpretacja danych/

E. Manuscript preparation/ Przygotowanie tekstu

F. Literature search/ Opracowanie piśmiennictwa

G. Funds collection/ Pozyskanie funduszy

\section{ORIGINAL ARTICLE}

JEL code: R11

Submitted:

December 2020

Accepted:

March 2021

Tables: 0

Figures: 2

References: 12

\section{ECONOMIC AND REGIONAL STUDIES}

STUDIA EKONOMICZNE I REGIONALNE

ISSN 2083-3725

Volume 14, No. 1, 2021

\title{
THE CONCEPT OF FINANCIAL CONTROL OF COMMUNES BASED ON THE EXPERIENCE OF POLAND
}

\section{KONCEPCJA KONTROLI FINANSOWEJ GMIN OPARTA NA DOŚWIADCZENIACH POLSKI}

\author{
Andriana Belia ${ }^{1(\mathrm{~A}, \mathrm{~B}, \mathrm{C}, \mathrm{E}, \mathrm{F})}$, Iryna Storonyanska ${ }^{1(\mathrm{D})}$
}

${ }^{1}$ M.I. Dolishniy Institute of Regional Research of NAS of Ukraine, Ukraine Instytut Badań Regionalnych im. M.I. Dolisznija przy Ukraińskiej Akademii Nauk, Ukraina

Belia, A., Storonyanska, I. (2021). The concept of financial control of communes based on the experience of Poland/ Koncepcja kontroli finansowej gmin oparta na doświadczeniach Polski. Economic and Regional Studies, 14(1), 14-25. https://doi.org/10.2478/ers-2021-0002

Abstract

Subject and purpose of work: The subject of the study are the elements of the Ukrainian financial control system. A combination of those elements enables formulating a concept which is directed at financial control of communes. The purpose of the study is identifying main directions of modernization of the Ukrainian financial control system over self-government units. Materials and methods: This study provides an analysis of government data and commercial statistics based on official studies, evaluation reports, program documents, website data, open research papers and promotional materials. The main elements and European experience that, in the author's opinion, are necessary for the construction of an effective finance control system of communes have been used in the construction of the concept of financial control over communes. Results: The key elements of the system of financial control over local self-government units of Poland are revealed. The improvement of financial control over communes in Ukraine and a number of organizational, economic and legal steps to optimize financial control at the local level are proposed. Conclusions: The article presents the main principles, measures and steps functioning in Polish financial control,which constitutes the basis for the formulation of a model of local finance control in Ukraine.

Keywords: communes, financial control system, state control, public control

\section{Streszczenie}

Przedmiot i cel pracy: Przedmiotem opracowania są elementy ukraińskiego systemu kontroli finansowej. Połączenie tych elementów pozwala na sformułowanie koncepcji ukierunkowanej na kontrolę finansową gmin. Celem pracy jest wskazanie głównych kierunków ukraińskiego systemu kontroli finansowej nad modernizacja samorzadu. Materiały i metody: Opracowanie opiera się na analizie źródeł danych statystyki rządowej i handlowej, oficjalnych opracowań, raportów ewaluacyjnych, dokumentów programowych, danych ze strony internetowej, artykułów naukowych i materiałów promocyjnych. Przy konstruowaniu Koncepcji kontroli finansowej gmin wykorzystano główne elementy i europejskie doświadczenia, które zdaniem autora sa niezbędne do zbudowania skutecznego systemu kontroli finansów gminy. Wyniki: Ujawniono kluczowe elementy systemu kontroli finansowej nad organami samorządu terytorialnego w Polsce. Przedstawiono propozycje zwiększenia kontroli finansowej gmin na Ukrainie. Zaproponowano szereg działań organizacyjnych, ekonomicznych i prawnych w celu optymalizacji kontroli finansowej na szczeblu lokalnym. Wnioski: W artykule przedstawiono główne zasady, mierniki i etapy funkcjonowania polskiej kontroli finansowej, które stanowią podstawę do sformułowania modelu lokalnej kontroli finansowej na Ukrainie.

Słowa kluczowe: gminy, system kontroli finansowej, kontrola państwowa, kontrola publiczna 


\section{Introduction}

The decentralization reform, which began in 2014, aimed to radically change the administrative structure of Ukraine through the creation of communes (In Poland, these formations are similar to the gmina). The creation of such communes also involves the redistribution of functions, budgets and financial flows in favor of newly formed associations. At the same time, Ukraine should not lose control over budget funds, which is the main task of many control bodies, but the lack of experience of reform and proper regulatory framework requires the experience of countries that have already reformed their own structure and formed a strong internal financial control system over local self-governments. That is why the need to implement world experience determines the relevance of this research work.

Poland carried out 2 reforms of decentralization of local self-government bodies - in 1987 and 2003. Municipalities of Poland (gmina) were provided with a wide range of social institutions (schools, medical institutions, etc.), which became one of the elements of the transformation of municipalities into practically independent administrative structures. During the decentralization reform, some gminas were liquidated due to their insolvency.

First of all we discover Polish experience over local self-government finance control system. The issue of public control is widely covered in the publications of Polish scholars. For example, in the works D. Budzeń (Budzeń 2015, p. 287-301) highlights the features of 25th years' experience of local government and the ability of society to influence the decisions of communes, in some research (e.g. WyporskaFrankiewicz, 2020) discovered control dividing and supervision (including public) of local governments and identifies the role of openness of information to the public, and in case research (Barczak, 2019, p. 1-8) especially highlights the environmental direction, and the commune's ability to influence the environmental situation in the region. There are global studies on public participation in local government, such as the work of the European Tribunal of Auditors in 2019, which cover public control in the context of the European Union.

The main elements and European experience that, in the author's opinion, are necessary for the construction of an effective communes finance control system were used in the construction of "The Concept Of Financial Control Of Communes". The authors hope that their work will contribute to understanding of authors' vision over necessity of actual Ukrainian financial control system's modernization. The subjects of the study are elements of Ukrainian financial control system. The purpose of the study is identifying main directions of Ukrainian financial control system over self-government unit modernization (including some Polish experience in budget sphere)

It should be noted that financial control can be classified differently, for example: from the subject of control (state, public, self-control), from the object

\section{Wstęp}

Rozpoczęta w 2014 roku reforma decentralizacyjna miała na celu radykalną zmianę struktury administracyjnej Ukrainy poprzez tworzenie gmin (podobne są właśnie w Polsce). Tworzenie takich gmin wiąże się również z redystrybucją funkcji, budżetów i przepływów finansowych na rzecz nowopowstałych organizacji. Jednocześnie Ukraina nie powinna tracić kontroli nad środkami budżetowymi, co jest głównym zadaniem wielu organów kontrolnych, ale brak doświadczenia $\mathrm{w}$ zakresie reform i odpowiednich ram regulacyjnych wymaga doświadczenia krajów, które już zreformowały własną strukturę i utworzyły silny system wewnętrznej kontroli finansowej nad samorządami terytorialnymi. Dlatego potrzeba wykorzystania doświadczenia światowego determinuje trafność tej pracy badawczej.

Polska przeprowadziła 2 reformy decentralizacji jednostek samorządu terytorialnego - w $1987 \mathrm{r}$. i 2003 roku. Gminy posiadają szeroką gamę insty tucji społecznych (szkoły, placówki medyczne itp.), które stały się jednym z elementów przekształcenia gmin $\mathrm{w}$ praktycznie niezależne struktury administracyjne. W trakcie reformy decentralizacyjnej część gmin została zlikwidowana w związku z niewypłacalnością.

Przede wszystkim poznajemy polskie doświadczenia związane z systemem kontroli finansów samorządowych. Zagadnienie kontroli publicznej jest szeroko poruszane w publikacjach polskich naukowców. Na przykład D. Budzeń w swoich pracach (2015, str. 287-301) zwraca uwagę na cechy 25-letniego doświadczenia samorządu terytorialnego i zdolności społeczeństwa do wpływania na decyzje gmin, w niektórych badaniach (np. 2020 r.) odkryto kontrolę podziału i nadzoru (w tym publicznego) samorządów oraz określono rolę jawności informacji dla opinii publicznej, a w badaniach przypadku (Barczak, 2019, str. 1-8) możliwość wpływania na sytuację środowiskową w regionie. Istnieją globalne badania dotyczące udziału społeczeństwa w działaniu samorządu terytorialnego, takie jak prace Europejskiego Trybunału Obrachunkowego w 2019 r., które obejmują kontrolę publiczną w kontekście Unii Europejskiej.

Do budowy „Koncepcji Kontroli Finansowej Gmin” wykorzystano główne elementy i doświadczenia europejskie, które zdaniem autora są niezbędne do budowy efektywnego systemu kontroli finansów gmin. Autorzy mają nadzieję, że ich praca przyczyni się do zrozumienia wizji autorów co do konieczności modernizacji faktycznego ukraińskiego systemu kontroli finansowej. Przedmiotem opracowania są elementy ukraińskiego systemu kontroli finansowej. Celem pracy jest identyfikacja głównych kierunków działania systemu kontroli finansowej w tym kraju nad modernizacją jednostek samorządu terytorialnego (w tym niektóre polskie doświadczenia w sferze budżetowej).

Należy zwrócić uwagę, że kontrolę finansową można zaklasyfikować odmiennie, na przykład: zgodnie z podmiotem kontrolnym (państwowa, publiczna, samokontrola), zgodnie z przedmiotem kontroli (finansowej, ustawodawczej itp.) lub z punktu 
of control (financial, legislative, etc.) or from the point of view of stages of control (previous, current, subsequent).

\section{Materials and methods}

This study is based on analyzing data sources of government and commercial statistics: official studies, evaluation reports, program documents, website data, open research papers and promotional materials. These sources help the authors outline the framework for discussing the relationship between public financial control bodies, commune, public and territorial communes.

The methods of analysis and synthesis of international experience formed the basis of the Concept of financial control of territorial communes. Such approach is due to both significant differences between countries and the experience of individual countries (e.g. Poland), which is similar to the experience gained by Ukraine during the decentralization reform.

\section{Poland approaches to financial control over local self-governments}

The experience of Poland is interesting especially in line with the independence of communes for example, the Ministry of Finance of Poland does not have access to many activity, does not participate in the collection of taxes and their spending (Poravsky, 2014; Strzelecki, 2014). The Ministry of Finance does not have access to the real estate. Such a register is maintained by the head of the commune (local government), who has an interest in the highest quality register, as it will ensure uninterrupted supply of the revenue side of the local budget. At the level of the commune, control over the calculation and payment of taxes is provided. And the verification of these processes is carried out by regional accounting chambers (Samaeva, 2014) - operating within their powers autonomously and are not subordinated to The Polish Supreme Chamber of Control.

The Ministry of Finance forms the national policy, calculates and sets the upper threshold of the tax rate and collects the share of taxes that are needed to cover national obligations, such as: development of national infrastructure, equalization and education subventions, financing of higher education, etc. (Gerus, 2016). Thus, there is a 2-tier control system with absolutely uncontrolled Polish Supreme Chamber of Control. Regional accounting chambers are an independent institution from Polish Supreme Chamber of Control. The voivode $\left(2^{\text {nd }} l v l\right.$ of Polish administrative structure - Jednostek Samorząu Terytorialnego) also exercises financial control of the subsidies from the state budget.

Important for Ukraine is the Polish experience in building a system of control over local governments: Budżet publiczny, Green budget (Lublin), Public Panel, co-financing from the local budget of public organizations, delegating certain executive powers, widzenia etapów kontroli (poprzedzająca, bieżąca, następcza).

\section{Materiały i metody}

Niniejsze opracowanie opiera się na analizie źródeł danych statystyk rządowych i komercyjnych: oficjalnych opracowań, raportów ewaluacyjnych, dokumentów programowych, danych internetowych, otwartych artykułów naukowych i materiałów promocyjnych. Źródła te pomagają autorom nakreślić ramy dyskusji na temat relacji między publicznymi organami kontroli finansowej, gminami publicznymi i terytorialnymi.

Metody analizy i syntezy doświadczeń międzynarodowych stanowiły podstawę Koncepcji kontroli finansowej gmin terytorialnych. Takie podejście wynika zarówno ze znacznych różnic między krajami, jak i doświadczeń poszczególnych krajów (np. Polski), które są podobne do doświadczeń zdobytych przez Ukrainę podczas reformy decentralizacyjnej.

\section{Podejście Polski do kontroli finansowej nad sa- morządami}

Doświadczenie Polski jest interesujące zwłaszcza w kontekście niezależności gmin, np. Ministerstwo Finansów nie ma dostępu do wielu działań, nie uczestniczy w poborze podatków i ich wydatkowaniu (Poravsky, 2014; Strzelecki, 2014). Ministerstwo Finansów nie ma dostępu do nieruchomości. Ich spis prowadzi wójt (samorząd), któremu zależy na jak najwyższej jakości rejestrze, gdyż zapewni on nieprzerwane zasilanie strony dochodowej budżetu gminy. Na poziomie gminy zapewniona jest kontrola nad naliczaniem i płaceniem podatków. A weryfikacji tych procesów dokonują regionalne izby obrachunkowe (Samaeva, 2014) - działające w ramach swoich kompetencji autonomicznie i nie podlegając Najwyższej Izbie Kontroli.

Ministerstwo Finansów kształtuje politykę państwa, wylicza i ustala górny próg stawki podatkowej oraz pobiera część podatków potrzebnych na pokrycie zobowiązań krajowych, takich jak: rozwój infrastruktury krajowej, subwencje wyrównawcze i edukacyjne, finansowanie szkolnictwa wyższego, itp. (Gerus, 2016). Tak więc istnieje dwustopniowy system kontroli z absolutnie niekontrolowana polską Najwyższą Izbą Kontroli. Regionalne izby obrachunkowe są niezależną instytucją należąca do Polskiej Najwyższej Izby Kontroli. Wojewoda (II poziom polskiej struktury administracyjnej - Jednostek Samorządu Terytorialnego) sprawuje również kontrolę finansową nad dopłatami z budżetu państwa.

Dla Ukrainy istotne są polskie doświadczenia $\mathrm{w}$ budowaniu systemu kontroli nad samorządami: Budżet publiczny, Zielony budżet (Lublin), Panel Publiczny, współfinansowanie z budżetu lokalnego organizacji publicznych, delegowanie określonych uprawnień wykonawczych, regularne konsultacje społeczne dotyczące ważnych społecznie kwestii, itp.

Poza tym, wraz z rozwojem infrastruktury ryn- 
regular public consultations on every socially important issue, etc.

Besides, with the development of market infrastructure, revenues from entrepreneurial activity and property in non-tax revenues of local budgets and in most post-socialist countries have increased. The amount of this type of non-tax revenues is over $40 \%$ in Poland, the Czech Republic and Slovenia, up to 20\% - in Bulgaria, Slovak Republic, Hungary and about 10\% - in Latvia and Romania (Bila, 2015, p. 659). Ukraine recorded one of the lowest indicators of this source of non-tax revenues among European countries, namely $2.4 \%$ in 2019.

It should be noted that from the point of view of the European Union, the presence of the same control functions of bodies of different branches of government (with minimal duplication in practice) can not be called an exclusively negative phenomenon (Bauer, Becker 2019), as the principle of transparency and efficiency is implemented and ensures the balance of different branches of government.

It should be noted that self-monitoring at the commune level is key to avoiding significant penalties, as it detects an extremely large number of violations at the current stage of commune financial transactions. Such activities, according to the current legislation of Poland, are carried out by authorized persons, including the auditor.

\section{The concept of financial control of communes}

The Ukrainian decentralization reform does not provide for a clear structure of financial control over the newly established over communes, as financial control issues are scattered among numerous regulations and recommendations of public authorities, public activists and non-profit donor organizations. Therefore, in our opinion, it is advisable to focus on the problems and obstacles that slow down the development of the financial control system at the local level.

Given the fact that according to the current legislation the main subjects of financial control by the state are the bodies of the State Audit Office, the Accounting Chamber, the State Treasury, the Office of Financial Control and the relevant budget managers, it is necessary to add to this list such subjects as public regional/ local organizations that ensure the implementation of public control. We should not forget about the presence of internal control and audit in communes.

This construction of financial control at the local level will provide a reliable platform for strengthening the effectiveness of control bodies and requires a number of measures, such as unification of the legal framework, rules of control bodies, optimization of cooperation mechanisms and exchange of information between public, state and internal control bodies. This construction we'd like to represent in The Concept of financial control of communes (Figure 1). kowej, wzrosły wpływy z działalności gospodarczej i majątku w pozapodatkowych wpływach budżetów lokalnych oraz w większości krajów postsocjalistycznych. Wysokość tego rodzaju przychodów niepodatkowych wynosi ponad $40 \%$ w Polsce, Czechach i Słowenii, do 20\% - w Bułgarii, Słowacji, na Węgrzech i około 10\% - na Łotwie i w Rumunii (Bila, 2015, s. 659). Ukraina zanotowała jeden z najniższych wskaźników tego źródła dochodów niepodatkowych wśród krajów europejskich - 2,4\% w 2019 roku.

Należy zauważyć, że z punktu widzenia Unii Europejskiej istnienie tych samych funkcji kontrolnych organów różnych gałęzi władzy (przy minimalnym powielaniu w praktyce) nie można nazwać zjawiskiem wyłącznie negatywnym (Bauer, Becker 2019), ponieważ zasada przejrzystości i skuteczności jest wdrażana i zapewnia równowagę między różnymi gałęziami władzy.

Należy zauważyć, że samokontrola na poziomie gminy jest kluczem do uniknięcia znaczących kar, ponieważ wykrywa niezwykle dużą liczbę naruszeń na etapie gminnych transakcji finansowych. Takie czynności, zgodnie z obowiązującym w Polsce prawem, wykonują osoby do tego uprawnione, w tym audytor.

\section{Pojęcie kontroli finansowej gmin}

Ukraińska reforma decentralizacyjna nie przewiduje jasnej struktury kontroli finansowej nad nowopowstałymi gminami, gdyż kwestie kontroli finansowej są rozproszone wśród licznych przepisów i zaleceń władz publicznych, działaczy publicznych i organizacji non-profit. Dlatego naszym zdaniem warto skupić się na problemach i przeszkodach, które spowalniają rozwój systemu kontroli finansowej na poziomie lokalnym.

Biorąc pod uwagę fakt, że zgodnie z obowiązującymi przepisami głównymi podmiotami kontroli finansowej państwa są organy Państwowej Izby Obrachunkowej, Izba Obrachunkowa, Skarb Państwa, Urząd Kontroli Finansowej oraz właściwe osoby zarządzające budżetem, konieczne jest dodanie do tej listy takich podmiotów, jak publiczne organizacje regionalne / lokalne, które zapewniają realizację kontroli publicznej. Nie można zapominać o istnieniu kontroli wewnętrznej i audytu w gminach.

Taka konstrukcja kontroli finansowej na poziomie lokalnym będzie stanowić wiarygodną platformę do wzmacniania efektywności organów kontrolnych i wymaga szeregu działań, takich jak ujednolicenie ram prawnych, regulaminów organów kontrolnych, optymalizacja mechanizmów współpracy i wymiana informacji pomiędzy publicznymi, państwowymi i wewnętrznymi organami kontroli. Tę konstrukcję chcielibyśmy przedstawić w Koncepcji kontroli finansowej gmin (Rysunek 1). 


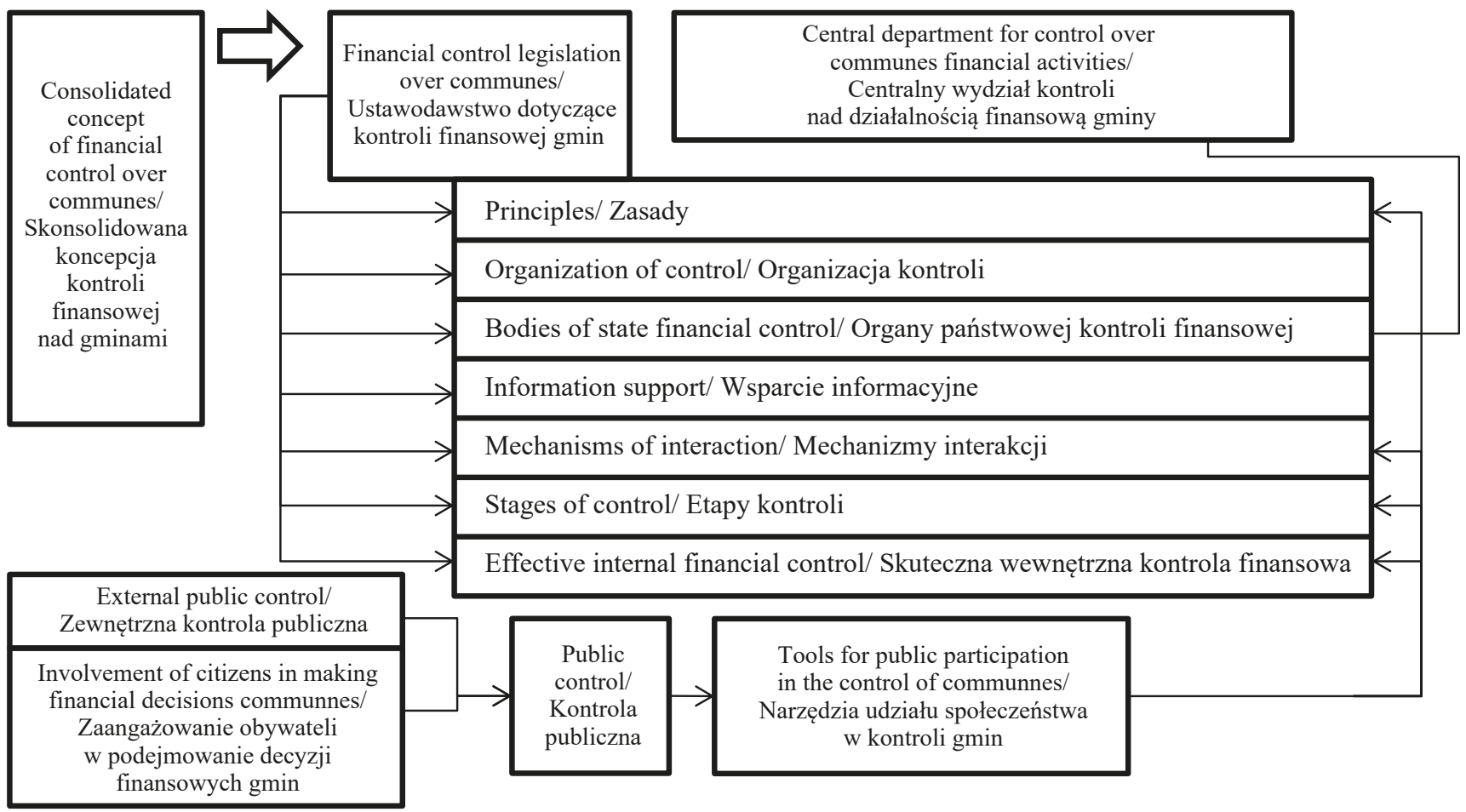

Figure 1. The Concept of Financial Control of Communes Rysunek 1. Koncepcja kontroli finansowej gmin

Source: Own elaboration.

Źródło: Opracowanie własne.

The substantiation of the proposed Concept will begin with the legal field (legislation) of financial control of communes, which is regulated by numerous regulations. Legal field are basis of all public authorities and local governments.

We propose to build a conceptual model of financial control of communes based primarily on compliance with the principles:

- Legality-violation of existing regulations should be prosecuted, and the activities of territorial communes should be based solely on permitted / not prohibited by law types and forms of activity. The inspection of controlling bodies is carried out within the current legal field by the tools defined and approved in accordance with the established procedure.

- Objectivity - this principle involves the formation of financial control over the facts, reliable and verified models. Assumptions should not affect the final result of inspections, but may be the basis for clarifying existing regulations.

- Reliability - this principle presupposes that the objects of control provide only reliable data that is proven and official for the communes.

- The principle of completeness - involves taking into account all the facts and circumstances to form a final conclusion on the results of inspections and the formation of the report. In addition, it provides for the analysis of all documents, transactions and circumstances, in the implementation of automated sampling and
Uzasadnienie proponowanej Koncepcji rozpocznie się od sfery prawnej (ustawodawstwa) kontroli finansowej gmin, której regulacje są liczne. Dziedzina prawna jest podstawą działania wszystkich władz publicznych i samorządów.

Proponujemy zbudowanie koncepcyjnego modelu kontroli finansowej gmin, opartego przede wszystkim na przestrzeganiu zasad:

- Legalność - naruszenie obowiązujących przepisów powinno być ścigane, a działalność gmin terytorialnych powinna opierać się wyłącznie na dozwolonych / nie zabronionych przez prawo rodzajach i formach działalności. Inspekcja organów kontrolnych jest prowadzona w ramach obowiązującego prawa za pomocą narzędzi określonych i zatwierdzonych zgodnie z ustaloną procedurą.

- Obiektywizm - zasada ta polega na tworzeniu finansowej kontroli, rzetelnych i sprawdzonych wzorów. Założenia nie powinny wpływać na ostateczny wynik kontroli, ale mogą być podstawą do doprecyzowania obowiązujących przepisów.

- Wiarygodność - zasada ta zakłada, że obiekty kontroli dostarczają tylko wiarygodnych i oficjalnych dla gmin danych.

- Zasada kompletności - polega na uwzględnieniu wszystkich faktów i okoliczności w celu sformułowania ostatecznego wniosku o wynikach kontroli i sporządzeniu raportu. Ponadto przewiduje analizę wszelkich dokumentów, transakcji i okoliczności, przy wdrażaniu automatycznego 
analysis of compliance with communes current legislation.

- The principle of openness and transparency also applies to the availability of financial data and (within the author's conceptual model) provides for maximum public involvement in the accumulation of information about possible violations of budget legislation and acquaintance with the results of inspections.

- Planning involves the formation of a consolidated plan for analysis and evaluation of communes' activities by state control bodies to comply with the conditions of transparency, completeness and avoidance of duplication of control measures of one object by several state control bodies.

These principles, as the basis of the concept of financial control of communes, allow determining the toolkit of control bodies that obliges government agencies to share available information. The formation of joint plans, the activities of which do not intersect, will facilitate the communes formation of necessary documents packages for submission to regulatory authorities. However, the activities of the supervisory authorities must be in accordance with these principles and have a sufficient professional level of auditors.

It should be noted that the list of controlling bodies is rather wide, and their activity, in essence, is subordinated either to the Verkhovna Rada of Ukraine (Ukrainian Parliament), or to the Cabinet of Ministers (Ukrainian Government) and the corresponding ministries. Thus, in our opinion, it is necessary to allocate the function of financial control for the authorized structure (like Polish Regional Chambers of Audit). This structure has been delegated to the appropriate powers to develop a methodology for control over regulatory authorities, quality control and completeness of reports and other measures. Accordingly, it is necessary to create a new hierarchy (organizational structure) in terms of regions and districts.

An important element of the proposed concept is public control, which is a third stakeholder. Society is more focused not on compliance with the law (even formal), but on the result of financial activities of the commune, social/infrastructural/economic effects.

In general, it should be noted that allocation this functionality is mandatory, as the consequences of decentralization reform and the variability of legislation, make it necessary to organize or find new ways of cooperation between control institutions.

Given the digitalization of the economy and society, active use of social networks and information infrastructure, the state, represented by the authorized body, should form an effective system of information exchange (results of inspections, violations, action plans, recommendations for communes' authorities to avoid mistakes and shortcomings, etc.).

In addition, the presentation of the results of annual, scheduled, unscheduled inspections to the public, including on social networks and at the official representation of the authorized body, should be key. doboru próby oraz analizę zgodności z obowiązującym prawem gmin.

- Zasada jawności i przejrzystości dotyczy również dostępności danych finansowych i (w ramach konceptualnego modelu autora) zapewnia maksymalne zaangażowanie społeczeństwa $\mathrm{w}$ gromadzenie informacji o ewentualnych naruszeniach prawa budżetowego i znajomość wyników kontroli.

- Planowanie polega na sporządzeniu skonsolidowanego planu analizy i oceny działalności gmin przez organy kontroli państwowej pod kątem przestrzegania warunków przejrzystości, kompletności i unikania dublowania działań kontrolnych jednego obiektu przez kilka organów kontroli państwowej.

Zasady te, jako podstawa koncepcji kontroli finansowej gmin, pozwalają na określenie zestawu narzędzi organów kontrolnych, które zobowiązują agencje rządowe do udostępniania dostępnych informacji. Tworzenie wspólnych planów, których działalność nie krzyżuje się, ułatwi gminom tworzenie niezbędnych pakietów dokumentów do przedłożenia organom regulacyjnym. Jednak działania organów nadzorczych muszą być zgodne z tymi zasadami i posiadać wystarczający poziom zawodowy audytorów.

Należy zauważyć, że lista organów kontrolnych jest dość szeroka, a ich działalność w istocie podlega Radzie Najwyższej Ukrainy (parlamentowi Ukrainy) lub Gabinetowi Ministrów (Rząd Ukrainy) i odpowiednim ministerstwom. Stąd naszym zdaniem konieczne jest przypisanie funkcji kontroli finansowej uprawnionej strukturze (jak np. Polskie regionalne izby obrachunkowe). Strukturze tej powierzono odpowiednie uprawnienia do opracowania metodologii kontroli nad organami regulacyjnymi, kontroli jakości oraz kompletności sprawozdań i innych środków. W związku z tym konieczne jest stworzenie nowej hierarchii (struktury organizacyjnej) regionów i powiatów.

Ważnym elementem proponowanej koncepcji jest kontrola publiczna, która jest trzecim interesariuszem. Społeczeństwo bardziej koncentruje się nie na zgodności z prawem (nawet formalnym), ale na wynikach działalności finansowej gminy, efektach społecznych / infrastrukturalnych / ekonomicznych.

Generalnie należy zauważyć, że alokacja tej funkcjonalności jest obowiązkowa, gdyż konsekwencje reformy decentralizacyjnej i zmienność ustawodawstwa powodują konieczność zorganizowania lub znalezienia nowych sposobów współpracy między instytucjami kontrolnymi.

Mając na uwadze cyfryzację gospodarki i społeczeństwa, aktywne korzystanie z portali społecznościowych i infrastruktury informacyjnej, państwo reprezentowane przez uprawniony organ powinno stworzyć efektywny system wymiany informacji (wyniki kontroli, naruszenia, plany działań, zalecenia dla władz gmin, aby uniknąć błędów i niedociągnięć itp.).

Ponadto kluczowe znaczenie powinno mieć przedstawianie wyników corocznych, zaplanowanych oraz niezaplanowanych inspekcji opinii publicznej, w tym 
An important place in the implementation of the Concept should be given to training the staff of regulatory authorities to work with the information system, which should improve the quality of operations and the number of inspections in a semiautomated mode.

Substantiating the conceptual model of financial control of the communes, we will dwell in more detail on the mechanisms of interaction. It should be noted that these mechanisms are implemented between public financial control bodies, between control bodies and communes, between control bodies and the public, as well as between communes and the public.

The number of mechanisms, being large enough, according our vision, has to be divided into 5 groups, namely:

- Economic (for example, financial sanctions to communes for violations of the law, surcharges for participation in public hearings, etc.).

- Organizational (eg, licensing, accreditation, standardization, etc.).

- Legal (updating of tools for monitoring and controlling the effectiveness of local budgets, legislative initiatives of the Cabinet of Ministers, etc.).

- Information (recommendations and conclusions on the results of inspections, publication of information on Internet resources, etc.).

- Combined (mechanisms of interaction of participants in the process of control of local budgets, where it is difficult to identify specific actions, for example, conducting inspections or a training seminar for communes' representatives).

In general, the mechanisms of interaction are related to the way the subject influences the object, where the subject and the object can be both state control bodies and communes or public associations.

Financial control over the communes budget process should take place at all stages of budgeting, because medium-term budget planning without taking into account strategic goals leads to gaps and additional unplanned expenditures in the budget year. At the same time, the lack of coverage in the report of information on the achievement of strategic or current goals may give the public impression of the inefficiency communes' budget year.

We should not forget the main goal of the Concept - to increase the efficiency of local budgets. This goal will be achieved only if there is sufficient current internal, external and state control. It is able to minimize the sanctions by timely detection of violations and implement measures to correct them.

Public control is an important and integral element of our Concept. In our opinion, since the commune is most interested in the effective use of communes' funds, public control can be implemented by maximally involving members of the public in the accumulation of violations information about budget process and legislation. The standardization of appeals (submitted to the authorized supervisory unit) and the involvement of members of the public w sieciach społecznościowych i podczas oficjalnej reprezentacji uprawnionego organu.

Istotne miejsce $\mathrm{w}$ realizacji Koncepcji powinno zająć szkolenie pracowników organów regulacyjnych do pracy z systemem informatycznym, co powinno podnieść jakość operacji i liczbę przeglądów prowadzonych w trybie półautomatycznym.

Opierając się na konceptualnym modelu kontroli finansowej gmin, bardziej szczegółowo zajmiemy się mechanizmami interakcji. Należy zauważyć, że mechanizmy te są wdrażane między publicznymi organami kontroli finansowej, między organami kontroli a gminami, między organami kontroli a społeczeństwem, a także między gminami a społeczeństwem.

Mechanizmy, które są dostatecznie duże, zgodnie z naszą wizją, należy podzielić na 5 grup, a mianowicie:

- Ekonomiczne (np. sankcje finansowe dla gmin za naruszenie prawa, dopłaty za udział w przesłuchaniach publicznych itp.).

- Organizacyjne (np. licencjonowanie, akredytacja, standaryzacja, itp.).

- Prawne (aktualizacja narzędzi monitorowania i kontroli efektywności budżetów lokalnych, inicjatywy legislacyjne Rady Ministrów itp.).

- Informacyjne (zalecenia i wnioski dotyczące wyników kontroli, publikacja informacji o zasobach internetowych itp.).

- Połączone (mechanizmy interakcji uczestników w procesie kontroli budżetów lokalnych, gdzie trudno jest wskazać konkretne działania, np. prowadzenie kontroli czy seminarium szkoleniowe dla przedstawicieli gmin).

Generalnie mechanizmy interakcji związane są ze sposobem, w jaki podmiot wpływa na przedmiot, przy czym podmiotem i przedmiotem mogą być zarówno organy kontroli państwowej, jak i gminy lub stowarzyszenia społeczne.

Kontrola finansowa procesu budżetowania gmin powinna odbywać się na wszystkich jego etapach, ponieważ średniookresowe planowanie budżetu bez uwzględnienia celów strategicznych prowadzi do luk i dodatkowych nieplanowanych wydatków w roku budżetowym. Jednocześnie brak ujęcia w raporcie informacji o realizacji celów strategicznych lub bieżących może sprawiać wrażenie nieefektywności roku budżetowego gmin.

Nie należy zapominać o głównym celu Koncepcji - zwiększeniu efektywności budżetów lokalnych. Cel ten zostanie osiągnięty tylko wtedy, gdy będzie istniała wystarczająca bieżąca kontrola wewnętrzna, zewnętrzna i państwowa. Jest ona w stanie zminimalizować sankcje poprzez terminowe wykrywanie naruszeń i wdrażanie środków w celu ich usunięcia.

Kontrola publiczna jest ważnym i integralnym elementem naszej koncepcji. Naszym zdaniem, ponieważ gmina jest najbardziej zainteresowana efektywnym wykorzystaniem środków gminnych, kontrolę publiczną można realizować poprzez maksymalne zaangażowanie obywateli w gromadzenie naruszeń informacji o procesie budżetowym i ustawodawstwie. Ujednolicenie odwołań (kierowanych do uprawnionej jednostki nadzorczej) oraz zaangażo- 
in the budget process will significantly expand the objectivity of the inspection's results.

In addition, it should be noted that the definition of strategic priorities for communes' development is impossible without taking about position of the local commune. Therefore both at the strategic and current stages of the budget process should be informed about communes' financial revenues and expenditures.

The Concept should have a certain term of performance/implementation of tasks to build an effective system of control over the activities of communes.

In this case, it is necessary to take into account the requirements of current legislation in terms of compliance with the budget process. Thus, according to the Strategy for reforming the public financial management system for 2017-2020 formed by the Cabinet of Ministers of Ukraine and the adopted amendments to the Budget Code of Ukraine, it is envisaged to carry out three-year medium-term planning from 2020. With this in mind, the author proposes to use a 4-year period in order for communes and state control bodies to be able to make the necessary changes to the current legal framework, to take the maximum possible organizational measures to increase communes' budgetary discipline. From this period, in our opinion, it is necessary to allocate half a year to develop the necessary regulations, 3 years to test and verify the quality of control and after control measures and half a year to report on the results of such control measures.

\section{Measures to implement the Concept}

Concept implementation requires the fulfillment of defined tasks. We group 7 tasks.

Task 1. Construction of a unified regulatory framework for financial control in communes, including systematization of approaches and methods for determining the effectiveness of control for the State Audit Office of Ukraine, the State Treasury Service of Ukraine, the Accounting Chamber of Ukraine, ministries and departments and other financial control bodies.

In our opinion, it is expedient to involve representatives of European structures that carry out financial control, supervision and audit of local governments in the formation of proposals to systematized regulatory framework.

Determine within the working group of representatives of state control bodies the list of communes, where pilot projects for systematic control measures will be implemented.

Task 2. Strengthen the concentration of control and inspection/ audit measures by focusing the actions of the State Audit Office of Ukraine and the Accounting Chamber of Ukraine on significant financial risks of economic crimes.

These institutions of state financial control have a high professional level as a tool for detecting and documenting violations of budgetary and financial legislation, significant fraud and risk. The use of a risk-oriented approach and interaction with the wanie społeczeństwa w proces budżetowy znacznie zwiększy obiektywizm wyników kontroli.

Należy też zauważyć, że określenie strategicznych priorytetów rozwoju gmin nie jest możliwe bez zajęcia stanowiska gminy lokalnej. Dlatego o dochodach i wydatkach finansowych gmin należy informować zarówno na strategicznym, jak i bieżącym etapie procesu budżetowego.

Koncepcja powinna mieć określony termin realizacji zadań, aby zbudować skuteczny system kontroli działalności gmin.

W takim przypadku konieczne jest uwzględnienie wymagań obowiązujących przepisów w zakresie zgodności z procesem budżetowym. W związku z tym, zgodnie ze Strategią reformy systemu zarządzania finansami publicznymi na lata 2017-2020 utworzoną przez Gabinet Ministrów Ukrainy oraz przyjętymi zmianami w Kodeksie budżetowym Ukrainy, przewiduje się przeprowadzenie trzyletniego planowania średniookresowego od 2020 r. Mając to na uwadze, autorka proponuje wykorzystanie 4-letniego okresu, aby gminy i organy kontroli państwowej były w stanie dokonać niezbędnych zmian w obowiązujących ramach prawnych, podjąć maksymalne możliwe działania organizacyjne w celu zwiększenia dyscypliny budżetowej gmin. Od tego czasu naszym zdaniem trzeba poświęcić pół roku na opracowanie niezbędnych regulacji, 3 lata na badanie i weryfikację jakości kontroli, przeprowadzeniu działań kontrolnych i pół roku na raportowanie wyników takich działań kontrolnych.

\section{Środki służące wdrożeniu Koncepcji}

Realizacja koncepcji wymaga realizacji określonych zadań. Grupujemy 7 zadań.

Zadanie 1. Budowa jednolitych ram regulacyjnych do kontroli finansowej w gminach, w tym usystematyzowanie podejść i metod określania skuteczności kontroli dla Państwowej Służby Obrachunkowej Ukrainy, Służby Skarbowej Ukrainy, Izby Obrachunkowej Ukrainy, resortów i innych organów kontroli finansowej.

Naszym zdaniem celowe jest zaangażowanie przedstawicieli europejskich struktur zajmujących się kontrolą finansową, nadzorem i audytem samorządów w tworzenie propozycji usystematyzowanych ram regulacyjnych.

Ustalenie w ramach grupy roboczej przedstawicieli państwowych organów kontrolnych listy gmin, w których będą realizowane pilotażowe projekty systematycznej kontroli.

Zadanie 2. Wzmocnienie koncentracji działań kontrolnych i kontrolno-audytowych poprzez skupienie działań Państwowej Służby Kontroli Ukrainy i Izby Obrachunkowej Ukrainy na istotnych ryzykach finansowych przestępstw gospodarczych.

Te instytucje państwowej kontroli finansowej posiadają wysoki poziom merytoryczny jako narzędzie wykrywania i dokumentowania naruszeń prawa budżetowego i finansowego, znaczących nadużyć i ryzyka. Stosowanie podejścia zorientowanego na ryzyko i współdziałanie z europejskimi instytucjami kontro- 
European control institutions will significantly strengthen control measures and return to the budget significant amounts of inefficiently used funds stolen by fraudsters.

Task 3. Improving the information support of state control bodies and communes by implementing necessary software and infrastructure.

First of all, with the involvement of the Ministry of Digital Transformation of Ukraine it is necessary to develop a new (improve the existing) automated information system for information exchange between state control bodies, law enforcement agencies and communes.

An additional necessary element should be a formalized toolkit for public appeals to control and supervisory bodies. It is necessary to formalize this process, which will identify the causes and separate the supporting facts from the opinions and assumptions of members of the public.

The automated information system for the exchange of information on control measures should:

- include cooperation on control over the use of budget funds and local resources between the following state control bodies: State Audit Service of Ukraine, State Treasury Service of Ukraine, Accounting Chamber of Ukraine, State Financial Monitoring Service, State Fiscal Service, Antimonopoly Committee of Ukraine, National Commission on Securities and Stock Market (for example, control over the issuance of local securities), other state bodies, which have the authority to exercise financial control over the activities of local governments.

On the other hand, the participants of this system should be communes in the person of authorized structural units, which should provide appropriate financial and management reporting.

- provide an opportunity for these control bodies to store information in the relevant databases, registers and automated systems, the operation of which is carried out from the State Budget of Ukraine. In addition to the consolidated databases, the information should also contain the results of the conducted inspections, which will make it possible, including verifying the implementation of the recommendations of the state financial control units.

- summarize information on planned measures to avoid excessive duplication.

Task 4. Building additional safeguards system of measures after the decentralization reform completion.

Decentralization reform is preparing the ground for the effective implementation of local budgets. At the same time, there is a list of problems that are not significant, but need to be addressed in the future (for example, a list of mandatory fields of forms for public reporting, the structure of the information hierarchy / information exchange system between control bodies, etc.). It is to address such clarifications and should focus on activities during the implementation of 4 tasks. lnymi znacznie wzmocni środki kontroli i przywróci do budżetu znaczne kwoty nieefektywnie wykorzystanych funduszy skradzionych przez oszustów.

Zadanie 3. Usprawnienie wsparcia informacyjnego organów kontroli państwowej i gmin poprzez wdrożenie niezbędnego oprogramowania i infrastruktury.

Przede wszystkim przy zaangażowaniu Ministerstwa Transformacji Cyfrowej Ukrainy konieczne jest opracowanie nowego (usprawnienie istniejącego) zautomatyzowanego systemu informatycznego wymiany informacji między organami kontroli państwowej, organami ścigania i gminami.

Dodatkowym niezbędnym elementem powinien być sformalizowany zestaw narzędzi do odwołań publicznych do organów kontrolnych i nadzorczych. Konieczne jest sformalizowanie tego procesu, który pozwoli zidentyfikować przyczyny i oddzielić fakty wspierające od opinii i założeń członków społeczeństwa.

Zautomatyzowany system informacyjny do wymiany informacji o środkach kontrolnych powinien:

- obejmować współpracę w zakresie kontroli wykorzystania środków budżetowych i zasobów lokalnych między następującymi organami kontroli państwowej: Państwowej Służby Kontroli Ukrainy, Służby Skarbowej Ukrainy, Izby Obrachunkowej Ukrainy, Państwowej Służby Monitorowania Finansów, Państwowej Służby Skarbowej, Komitetu Antymonopolowego Ukrainy, Krajowej Komisji Papierów Wartościowych i Giełdy (np. kontrola emisji lokalnych papierów wartościowych), inne organy państwowe, które mają uprawnienia do sprawowania kontroli finansowej nad działalnością samorządów.

Z drugiej strony uczestnikami tego systemu powinny być gminy w osobie uprawnionych jednostek strukturalnych, które powinny zapewnić odpowiednią sprawozdawczość finansowo-zarządczą.

- zapewnić tym organom kontrolnym możliwość przechowywania informacji $w$ odpowiednich bazach danych, rejestrach i zautomatyzowanych systemach, których obsługa jest prowadzona z budżetu państwa Ukrainy. Oprócz skonsolidowanych baz danych informacja powinna zawierać również wyniki przeprowadzonych kontroli, co umożliwiweryfikację realizacji zaleceń państwowych jednostek kontroli finansowej.

- podsumowywać informacje na temat planowanych środków w celu uniknięcia nadmiernego powielania.

Zadanie 4. Budowa dodatkowego systemu zabezpieczeń środków po zakończeniu reformy decentralizacyjnej.

Reforma decentralizacji przygotowuje grunt pod skuteczną realizację budżetów lokalnych. Jednocześnie istnieje lista problemów, które nie są istotne, ale wymagają rozwiązania w przyszłości (np. lista obowiązkowych pól formularzy do celów sprawozdawczości publicznej, struktura hierarchii informacji / systemu wymiany informacji między organy kontrolne itp.). Ma ona zająć się takimi wyjaśnieniami i powinna skupić się na działaniach podczas realizacji 4 zadań. 
Task 5. Use of human resources of supervisory and control bodies in Ukraine.

To solve this problem it is necessary to implement 3 groups of measures. First, it is necessary to train and develop highly qualified personnel in the control bodies, for which it is necessary to conduct regular professional development activities (seminars, trainings, conferences, etc.) and advanced training.

Secondly, it is necessary to train highly qualified personnel in communes' structural units responsible for compliance with and implementation of budgetary and financial legislation. Such events, in our opinion, should be regular, and responsible persons should attend them regular participate such activities. This term is due to the variability of current legislation (Figure 2).
Zadanie 5. Wykorzystanie zasobów ludzkich organów nadzorczych i kontrolnych na Ukrainie.

Aby rozwiązać ten problem, konieczne jest wdrożenie 3 grup działań. Po pierwsze, konieczne jest przeszkolenie i rozwój wysoko wykwalifikowanej kadry w jednostkach certyfikujących, dla których konieczne jest prowadzenie regularnych działań doskonalenia zawodowego (seminaria, szkolenia, konferencje, itp.) oraz zaawansowanych szkoleń.

Po drugie, konieczne jest przeszkolenie wysoko wykwalifikowanej kadry w gminnych jednostkach strukturalnych odpowiedzialnych za przestrzeganie i wdrażanie przepisów budżetowych i finansowych. Naszym zdaniem takie wydarzenia powinny być cykliczne, a osoby odpowiedzialne powinny regularnie uczestniczyć w takich zajęciach. Termin ten wynika ze zmienności obowiązującego prawodawstwa (Rysunek 2).

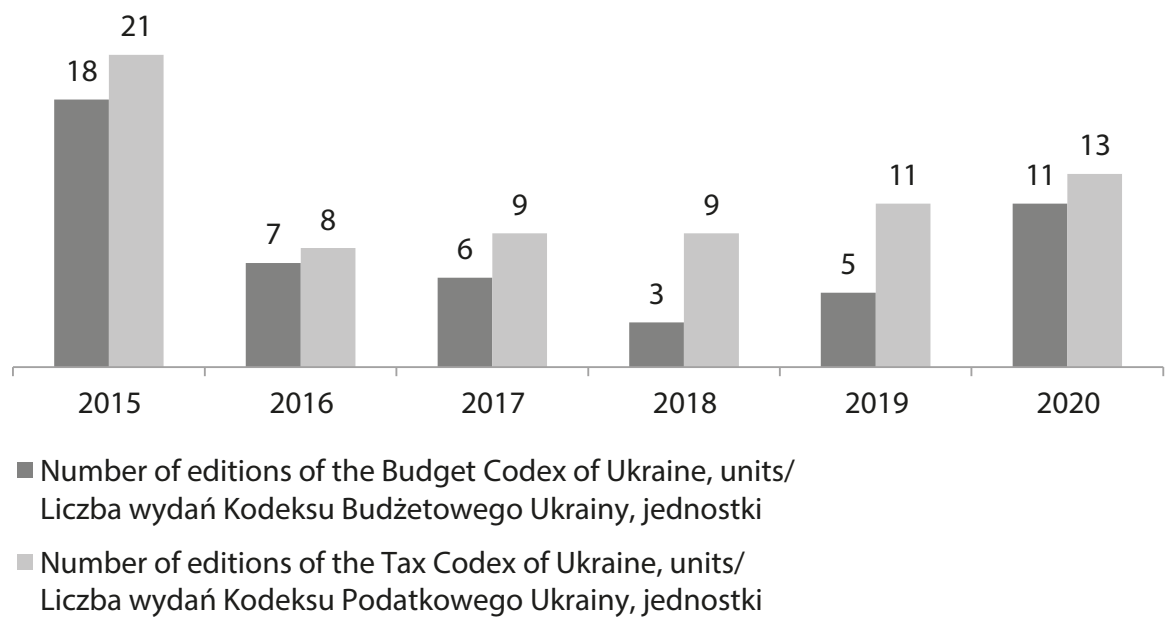

Figure 2. Changes in the codex` of financial law in Ukraine during 2015-2020

Rysunek 2. Zmiany w kodeksie prawa finansowego na Ukrainie w latach 2015-2020

Source: Compiled by the author, based on Budget and Tax Codex` of Ukraine.

Źródło: Opracował autor na podstawie Kodeksu Budżetowego i Podatkowego Ukrainy.

According to the above figure, there are numerous changes in the current Budget and Tax Codes of Ukraine, and therefore the need to familiarize and explain the main changes is justified and appropriate for responsible employees of communes.

The third point is the need to retain highly qualified personnel in state control bodies. And first of all, this can be achieved through a sufficient level of remuneration, which can be achieved with sufficient funding, which, in turn, will allow state control units to perform their assigned functions in full.

According to the above figure, there are numerous changes in the current Budget and Tax Codes of Ukraine, and therefore the need to familiarize and explain the main changes is justified and appropriate for responsible employees of communes.

The third point is the need to retain highly qualified personnel in state control bodies. And first of all, this can be achieved through a sufficient level of remuneration, which can be achieved with sufficient funding, which, in turn, will allow state control units perform their assigned functions in full.
Jak wynika z powyższego rysunku, $\mathrm{w}$ obowiązujących Kodeksach Budżetowych i Podatkowych Ukrainy zachodzą liczne zmiany, stąd konieczność zapoznania się i wyjaśnienia głównych zmian jest uzasadniona i właściwa dla odpowiedzialnych pracowników gmin.

Trzecia kwestia to konieczność utrzymywania wysoko wykwalifikowanej kadry w państwowych organach kontrolnych. Przede wszystkim można to osiągnąc poprzez wystarczający poziom wynagrodzenia, który jest możliwy przy odpowiednim finansowaniu, co z kolei pozwoli państwowym jednostkom kontrolnym na pełne wykonywanie powierzonych im funkcji.

Jak wynika z powyższego rysunku, w obowiązujących Kodeksach Budżetowych i Podatkowych Ukrainy zachodzą liczne zmiany, stąd konieczność zapoznania się z nimi i wyjaśnienia ich jest uzasadniona i właściwa dla odpowiedzialnych pracowników gmin.

Trzecia kwestia to konieczność utrzymywania wysoko wykwalifikowanej kadry w państwowych organach kontrolnych. Można to przede wszystkim osiągnąc poprzez dostateczny poziom wynagrodze- 
Task 6. Formation of an effective mechanism of partnership relations between control units, between control units and communes, between control bodies and business entities.

State control bodies in order to increase the level of significance of the audit, the formation and implementation of partnerships with public authorities, local governments and businesses during the planning and conduct of the audit should standardize the procedure for planning and conducting public financial audit at the request of authorities and entities. In addition, in order to form in public authorities, local governments, business entities an understanding of the essence of audit and the conceptual approaches on the basis of which it is organized, operates and develops, financial control bodies together with public authorities, local governments and sub business entities, scientific institutions, international experts will hold round table meetings, seminars, conferences, etc. on this issue.

Task 7. Together with the state control bodies and the Ministry of Development of Communes and Territories of Ukraine it is necessary to form criteria for internal control bodies (not only audit as a unit of further control, but also internal financial control bodies of communes).

Task 8. Jointly by state control bodies, the Ministry of Development of Communes and Territories of Ukraine and public representatives to hold seminars/ round tables/conferences to determine the main principles, organizational provisions and proposals for changes in legislation to involve the public in active external financial control at the local level. As Example it may be possibility of discharge procedure for the mayor's, or online control over local governments from Polish experience.

Fulfillment of the set tasks will allow to harmonize relations in the field of local finances and to satisfy the maximum number of participants of process.

\section{Conclusions}

Creation and implementation of this Concept will allow reform conceptual bases of a single legislative foundation and normative-methodological support of financial control of communes of Ukraine, systematize and standardize instruments of state financial control, integrate and coordinate functions of control bodies, local self-government and public representatives and ensure clear division of powers between them.

Minimize the risks of possible errors, violations and abuses in the financial and budgetary spheres and reduce the loss of budgetary resources, focus control activities on significant abuses and violations.

Heads of local governments' responsibility will nia, który można osiągnąć przy odpowiednim finansowaniu, co z kolei pozwoli państwowym jednostkom kontrolnym na pełne wykonywanie powierzonych im funkcji.

Zadanie 6. Stworzenie efektywnego mechanizmu partnerskich relacji między jednostkami kontrolnymi, między jednostkami kontrolnymi a gminami, między organami kontroli a podmiotami gospodarczymi.

Państwowe organy kontrolne $\mathrm{w}$ celu podniesienia rangi kontroli, zawiązania i realizacji partnerstw z władzami publicznymi, samorządami terytorialnymi i przedsiębiorcami w trakcie planowania i przeprowadzania kontroli powinny ujednolicić procedurę planowania i przeprowadzania publicznego audytu finansowego na żądanie władz i innych podmiotów. Ponadto, w celu ukształtowania we władzach publicznych, samorządach, podmiotach gospodarczych zrozumienia istoty audytu oraz podejść koncepcyjnych, w oparciu, o które jest on organizowany, funkcjonuje i rozwija sie, organy kontroli finansowej wraz $\mathrm{z}$ organami publicznymi, samorzady terytorialne, podmioty gospodarcze, instytucje naukowe oraz eksperci międzynarodowi będą organizować spotkania przy okrągłym stole, seminaria, konferencje itp. na ten temat.

Zadanie 7. Wraz z organami kontroli państwowej oraz Ministerstwem Rozwoju Gmin i Terytoriów Ukrainy konieczne jest ustalenie kryteriów dla organów kontroli wewnętrznej (nie tylko audytu jako jednostki dalszej kontroli, ale także wewnętrznych organów kontroli finansowej gmin).

Zadanie 8. Wspólnie z organami kontroli państwowej, Ministerstwo Rozwoju Gmin i Terytoriów Ukrainy oraz przedstawiciele społeczeństwa mają zorganizować seminaria / okrągłe stoły / konferencje w celu ustalenia głównych zasad, przepisów organizacyjnych i propozycji zmian w ustawodawstwie w celu zaangażowania społeczeństwa w aktywną zewnętrzną kontrolę finansową na szczeblu lokalnym. Przykładem może być możliwość udzielenia absolutorium burmistrzowi lub kontroli on-line nad samorząami na podstawie polskich doświadczeń.

Realizacja postawionych zadań pozwoli zharmonizować relacje w zakresie finansów lokalnych i zapewnić maksymalną liczbę uczestników procesu.

\section{Wnioski}

Stworzenie i wdrożenie tej Koncepcji pozwoli zreformować koncepcyjne podstawy jednej podstawy legislacyjnej i normatywno-metodologiczne wsparcie kontroli finansowej gmin Ukrainy, usystematyzować i ujednolicić instrumenty państwowej kontroli finansowej, zintegrować i skoordynować funkcje organów kontrolnych, samorządu terytorialnego i przedstawicieli publicznych oraz zapewnić jasny podział kompetencji między nimi.

Powinna mieć miejsce minimalizacja ryzyka możliwych błędów, naruszeń i nadużyć w sferze finansowej i budżetowej oraz ograniczenie możliwości utraty środków budżetowych oraz koncentracja działań kontrolnych na znaczących nadużyciach i naruszeniach. 
increasing, these helps to avoid of their erroneous, ineffective, and criminal management decisions. Besides it minimize the loss of budget resources during the decentralization reform at the same time as reforming the accounting and internal control system.

Create an integrated automated information system of state control over the management and use of local resources by local governments. Within the framework of this system, to establish and institutionally provide mechanisms for interaction and exchange of information between state financial control bodies, financial control bodies and law enforcement bodies.

Finally, implementation of this Concept increase the level of citizens' trust in state institutions and reduce social tensions in society by improving the quality of public awareness of the results of the work of state control bodies.

The following research should be devoted to the practical steps of implementation of the Concept in the activities of financial control over the use of budget funds of communes of Ukraine.
Odpowiedzialność szefów samorządów będzie rosła, co pomoże uniknąć ich błędnych, nieskutecznych i przestępczych decyzji zarządczych. Poza tym minimalizuje to utratę środków budżetowych podczas reformy decentralizacyjnej, jednocześnie reformując rachunkowość i system kontroli wewnętrznej.

Należy stworzyć zintegrowany zautomatyzowany system informatyczny kontroli państwa nad zarządzaniem i wykorzystaniem lokalnych zasobów przez samorzady. W ramach tego systemu należy również ustanowić i instytucjonalnie zapewnić mechanizmy interakcji i wymiany informacji pomiędzy państwowymi organami kontroli finansowej, pozostałymi organami kontroli finansowej i organami ścigania.

Wreszcie realizacja tej Koncepcji podnosi poziom zaufania obywateli do instytucji państwowych i zmniejsza napięcia społeczne poprzez poprawę jakości społecznej świadomości wyników pracy organów kontrolnych.

Poniższe badania należy poświęcić praktycznym etapom wdrażania Koncepcji w działaniach kontroli finansowej wykorzystania środków budżetowych gmin Ukrainy.

\section{References/ Literatura:}

1. Barczak, A. (2019). Zadania kontrolno-nadzorcze samorządu terytorialnego w zakresie ochrony środowiska. Ekspertyzy i opracowania, 96, 1-8 (in Polish).

2. Bauer, M.W., Becker, S. (2019). Public Administration in Germany: Problems and Potential of a Fragmented Community. International Journal of Public Administration, 42(11), 950-960. https://doi.org/10.1080/01900692.2018.1560318

3. Bila, L. (2015). Spil'ni ta vidminni rysy podatkovykh system krayin Yevropeys'koho Soyuzu ta Ukrayiny [Common and distinctive features of the tax systems of the European Union and Ukraine]. Hlobal'ni ta natsional'ni problemy [Global And National Economic Problems], 6, 656-661 (in Ukrainian).

4. Budget Codex of Ukraine. Downloaded from: https://zakon.rada.gov.ua/laws/show/2456-17/card4\#Current (Access: 01.12.2020).

5. Budzeń, D. (2015). Ewolucja systemu kontroli wewnętrznej w jednostkach samorządu terytorialnego na przestrzeni 25 lat samorządności w Polsce. Ruch prawniczy, ekonomiczny i socjologiczny, 77(3), 287-301 (in Polish). https://doi.org/10.14746/rpeis.2015.77.3.20

6. European Court of Auditors (2020). Audit Reports and Opinions. Downloaded from: https://www.eca.europa.eu/en/Pages/ AuditReportsOpinions.aspx (Access: 01.12.2020).

7. Gerus, A. (2016). Uroky Pol'shchi v pytannyakh finansovoyi detsentralizatsiyi [Lessons of Poland in matters of financial decentralization]. Downloaded from: https://www.prostir.ua/?blogs=uroky-polschi-v-pytannyah-finansovoji-detsentralizatsiji (Access: 01.12.2020) (in Ukrainian).

8. Poravsky, A. (2014). V Pol'she byudzhety mestnykh obshchin sostavlyayut tret' byudzheta strany - glava Soyuza pol'skikh gorodov [In Poland, local community budgets make up a third of the country's budget - head of the Union of Polish Cities]. Downloaded from: https://delo.ua/econonomyandpoliticsinukraine/v-polshe-bjudzhety-mestnyh-obschin-sostavljajut-tret-bjudzheta-s-283137/ (Access: 01.12.2020) (in Ukrainian).

9. Samaeva, Y. (2014). Dazhe glupost' gosudarstva chasto stoit bol'shikh deneg [Even the stupidity of the state often costs a lot of money]. Downloaded from: https://zn.ua/internal/prezident-naivysshey-izby-kontrolya-polshi-kshishtof-kvyatkovskiydazhe-glupost-gosudarstva-chasto-stoit-bolshih-deneg-265823_html (Access: 01.12.2020) (in Ukrainian).

10. Strzelecki, A. (2014). Legal and economic aspects of the financial independence of communes in Poland. Law and Administration in Post-Soviet Europe, 1, 38-50. https://doi.org/10.2478/lape-2014-0004

11. Tax Codex of Ukraine. Downloaded from: https://zakon.rada.gov.ua/laws/show/2755-17/card4\#Current (Access: 01.12.2020).

12. Wyporska-Frankiewicz, J. (red.) (2020). Kontrola wykonywania zadań i nadzór nad jednostkami samorządu terytorialnego. Warszawa: Wolters Kluwer Polska (in Polish). 